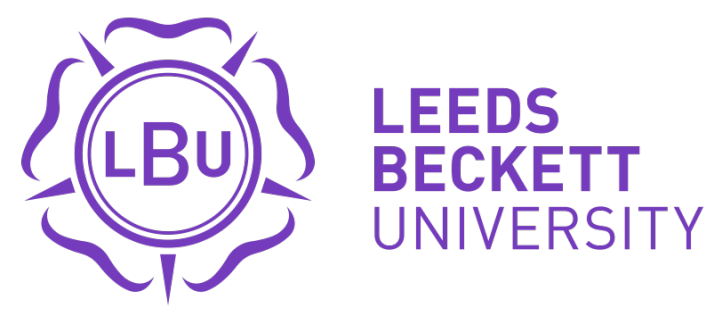

Citation:

Topic, M and Tench, R and Moreno, A (2017) Male and Female Communication, Leadership Styles and the Position of Women in Public Relations. Interactions: Studies in Communication and Culture, 8 (2-3). ISSN 1757-2681 DOI: https://doi.org/10.1386/iscc.8.2-3.231_1

Link to Leeds Beckett Repository record:

https://eprints.leedsbeckett.ac.uk/id/eprint/4202/

Document Version:

Article (Accepted Version)

The aim of the Leeds Beckett Repository is to provide open access to our research, as required by funder policies and permitted by publishers and copyright law.

The Leeds Beckett repository holds a wide range of publications, each of which has been checked for copyright and the relevant embargo period has been applied by the Research Services team.

We operate on a standard take-down policy. If you are the author or publisher of an output and you would like it removed from the repository, please contact us and we will investigate on a case-by-case basis.

Each thesis in the repository has been cleared where necessary by the author for third party copyright. If you would like a thesis to be removed from the repository or believe there is an issue with copyright, please contact us on openaccess@leedsbeckett.ac.uk and we will investigate on a case-by-case basis. 
Ralph Tench, Angeles Moreno \& Martina Topić

Leeds Beckett University, Leeds Business School

562 Rose Bowl, Portland Crescent

LS1 3HE, Leeds, West Yorkshire

United Kingdom

Male and Female Communication, Leadership Styles and the Position of Women in Public Relations

\begin{abstract}
This article discusses results of the largest European survey among communication and public relations (PR) practitioners in regards to the position of women in the industry. The survey was conducted online among communication and PR practitioners from 42 European countries. Using communication theories on differences in communication styles among men and women, we present and discuss results on managerial skills, differences in the communication styles, and traditional views on differences between men and women in PR. The results suggest differences in communication styles among male and female practitioners, where women prefer non-personal communication methods while men prefer more personal forms of communication. The results thus go directly against data showing that women prefer intimacy and building relationships and against the frequently stated arguments for differentiated approaches to communication styles.
\end{abstract}

Key words: women, public relations, communication styles, communication method

\title{
Introduction
}

A significant body of feminist literature has been arguing for decades that women are in less favourable positions than men due to the predominant influence of patriarchy that continues to 
exist. This particularly applies to the position of women in work where women are often underpaid, progression is harder, are treated less favourably, encounter barriers to enter the political process or progress in careers, or face the expectation to fulfil expected roles (see e.g. Labelle et al, 2015; Teasdale, 2013; Verboord, 2012; Alaez-Aller, 2011; Dozier, 2010; Eveline \& Todd, 2009; Thorney \& Thörnqvist, 2009; Torenly, 2006; Dozier et al, 2007; Van Zoonen, 2004; Katila \& Meriläinen, 2002; Scharrer, 2002; Grunig et al, 2001; Eichenbaum \& Orbach, 1999; Templin, 1999; Houchin-Winfield, 1997).

The situation is not better when it comes to business because scholars systematically report severe discrepancies with the wage gap, the glass ceiling, lower pay in professions traditionally occupied by women, a lack of women in managerial positions, and among CEOs and corporate directors (Labelle et al, 2015; Teasdale, 2013; Alaez-Aller, 2011; Dozier, 2010; Eveline \& Todd, 2009; Thorney \& Thörnqvist, 2009; Dozier et al, 2007; Katila \& Meriläinen, 2002). However, what is particularly troubling is that not only the situation has not historically changed, but certain countries tried to re-introduce policies that were excluded from the legal system as discriminatory towards women, such as all male teachers for Catholic schools (Eveline \& Todd, 2009).

On the other hand, it seems that not only do women suffer inequality because legislation is slow to implement but some things have changed and there is an underlying patriarchal assumption. For example, when it comes to the wage gap women are clearly treated less favourably (Dozier, 2010; Dozier et al, 2007; O’Neil, 2003; Yeomans, 2014, 2013, 2010), however, when it comes to approving flexible working hours because of family duties then it is women who get these requests approved more often than men in similar situations (Teasdale, 2013). This does not prove that some things have changed, but that it is still seen that women's natural place is at home and, thus, when a women asks for this arrangement the approval comes 
naturally, whereas men who need this service can struggle because of patriarchal discrimination against men who are also expected to fulfil the masculine role.

When it comes to communication, differences between men and women are also generally considered to still exist. It is largely perceived that women and men communicate differently, which sometimes contributes to the lack of understanding between them (Tannen, 1986, 1990; Suciu, 2013, 2008). When it comes to public relations (PR), the PR industry is nowadays a predominantly female industry (Wyatt, 2013; Fitch, 2010; Aldoory \& Toth, 2002). This, however, does not mean that women are occupying senior positions (Grunig et al, 2001; Rush et al, 2004; Place, 2015; Fitch et al, 2016; Fitch, 2016; Tench \& Topić, 2016), and the leadership discrepancy became a subject of interest of the third wave of feminism given the rising role of women in education and employment, but insufficient participation of women in politics and leadership (Merchant, 2012). ${ }^{1}$ An additional problem with PR is that because it became a field where there is a majority of female employees, stereotypes of PR practitioners emerged such as for example the PR Bunny or a PR Girl (Fröhlich and Peters, 2007).

Nevertheless, even though women form the majority of employees in PR, a wage and position gap still exists. For example, the Chartered Institute of Public Relations reported there is still a significant wage gap between men and women working in PR, and this difference exists even though it cannot be explained by part-time positions or any other factor that could normally affect the wage gap (CIPR State of the Profession, 2015, 2016; Fitch et al, 2016; Fitch, 2016a). In addition, the European Communication Monitor (ECM) systematically reports on the wage gap among male and female communication and PR practitioners (Zerfass et al, 2007, 2015).

\footnotetext{
${ }^{1}$ The first wave of feminism was focused on general equality of women, and the debates were primarily centred on political equality, and women's right to vote in particular (Dickenson 1993; Goldman 2001; Lehmann 2001). The second wave of feminism then continued the plight for women equality by tackling cultural discrimination and struggling to incorporate gender equality in legal systems (Norton 2005; McCann 2008). The third wave continued with plight for greater involvement of women in politics and tackled issues of racism (Merchant 2012).
} 
However, because women have entered the PR field in large numbers some started to speak of the feminisation of PR, and as soon as women started to enter the field in higher numbers debates on why this has happened occurred (Yeomans, 2010; Aldoory, 2005). Some scholars argued that the reason why women managed to enter PR in such high numbers is because women are more inclined towards emotional work and they are more friendly and kind, all of which are skills necessary for PR practitioners (Hochschild, 1983, 2003, 2008; Yeomans, 2014, 2013, 2010), with which traditional views on women have actually been additionally enforced even by scholars. In addition, term for these differences is known as 'genderlect', which is seen as tied not to "geography or to family background or to a role but to the speaker's sexual gender" (Suciu, 2013: 1).

In 2014, the European Communication Monitor survey was conducted on a sample of 2,777 public relations (PR) and communication practitioners in 42 European countries. In this article, we will present and discuss results on managerial skills among male and female practitioners and differences in the use of communication among men and women. The aim of the article is to address the situation in the public relations (PR) and communication industries, and to debate whether we can say that women prefer different communication channels than men and whether these differences are in connection with leadership styles.

\section{Communication differences between men and women}

When it comes to communication styles, scholars systematically report on differences between men and women (Coates, 1989; Tannen, 1990; Merchant, 2012; Zerfass et al, 2014). In other words, men are understood to speak the language that expresses independence, competitiveness and enforces status while women are seen to speak in a way that enables connection and intimacy (Tannen, 1990). This view follows the view of leadership qualities where women are seen as emotional and affectionate and thus less able to be effective leaders. 
Following the assumed differences in communication styles between men and women, two approaches to studying differences in communication developed, i.e. the dominance approach and the difference approach. In the first case, men are seen to subordinate women through their different use of communication, while in the second case differences in communication are understood through belonging to two different sub-cultures (White, 2003). The dominance approach has been firstly developed by Robin Lakoff (1975) in her classic work where she analysed what she perceived as a typical women's language and the use of terms by women. In her opinion, women are expected to demonstrate their weakness and subordination in the way they speak (Cameron et al, 1989; White, 2003; Suciu, 2008). In other words, Lakoff (1975) argued that women are denied the right to speak as strongly as men because of which they are pushed into triviality and uncertainty in their speech, and because of that women are always subject to stereotypes (Goldberg, 1994). Her research has been criticised as biased because it relied on personal observation too much, however, her findings/observation pointed to the direction of future feminist research (Stainton Rogers, 2011).

On the other hand, according to the difference approach, men and women communicate in different ways as a result of numerous factors and not necessarily the male's desire to dominate. According to this view, men are committed to sharing information while women are more interested in the interaction, and these differences come from the socialisation process that differs for men and women, or boys and girls (Maltz \& Borker, 1982). Tannen (1986; 1990) added to the research on differences and emphasized that women's speech is 'rapport talk' while men's speech is 'report-talk', i.e. women are committed to networking and developing connections while men are committed to exposing their skills and independence. This furthermore means that women are committed to developing solidarity while men seek hierarchy. Furthermore, women use communication to develop relationships while men use communication to establish dominance. These differences in communication styles often lead 
to miscommunication (Ersoy, 2008), or to what Tannen (1990) calls meta-messages that men and women sometimes do not read properly during the interaction.

Differences in communication styles are believed to come from socialisation, and initial upbringing in particular. Yule (2006) stated that communication is a learned skill, and that men and women learn this skill in different ways. This means that while all human beings are able to learn to speak, how we speak is in large part a result of our socialisation and upbringing. In addition, our communication style is influenced by our cultural and individual differences, and this also affects the way we listen to the others (Tannen, 1995). According to Tannen (1995), men and women learn how to speak in different ways through their upbringing and the socialisation process.

For example, "girls tend to learn conversational rituals that focus on the rapport dimension of relationships whereas boys tend to learn rituals that focus on the status dimension. Girls tend to play with a single best friend or in small groups, and they spend a lot of time talking" (Tannen, 1995: 140). This furthermore means that, according to Tannen (1995), girls do not compete so much with each other but downplay differences to appear all the same and to find a common spot to unite them so that no girl in the group feels offended or less valuable. On the other hand, boys tend to play in different ways, i.e. in large groups and they are not treated equally but they compete for the position of a leader. In their group, being bossy is not problematic as with girls, and they do not seek comfort but competition and leadership (Tannen, 1995). Consequentially, both girls and boys need to communicate with each other to create group belonging and to make the group work, and this is where the differences in communication firstly occur.

Another difference importantly pointed out by Tannen (1995) is the use of "I" and "we" where men always emphasize their individual accomplishments while women use group belonging, 
and this is often seen even in work organizations. For example, women will say "we" when mentioning that their company is hiring new staff even if she is in charge, while men tend to say "I", and this applies to all other situations when women and men are supposed to emphasize their role and/or achievements (Tannen, 1995). Because of this, differences in communication style between men and women are often described using the term 'genderlect', which means that 'genderlect' is similar to the dialect just that it explains differences that are not tied to "geography or to family background or to a role but to the speaker's sexual gender" (Suciu, 2013: 1). This term is clearly intertwined with the difference approach because women and men are, in this view, seen as fundamentally different in the way they socialise, interact and consequentially communicate (Tannen 1986, 1990).

As emphasized by Tannen (1990), all people are unique in their behaviour but there are some common traits when it comes to men and women as well as with people from different countries and different regions within the same country, and even though it may seem stereotypical to label women in one way and men in the other, the difference approach of emphasizing differences and learning to live with them argues it is the only feasible way. Another reason for these differences in seeing the purpose of conversation through different lenses, i.e. women use conversation to create relationships, while men use it to achieve an outcome and establish a dominant position (Leaper, 1991; Maltz \& Borker, 1982; Wood, 1996; Mason, 1994).

The concept of genderlect can be related to patriarchy because gender debates have always been intertwined with identity. As argued by Butler (1990), gender is something people do as a matter of choice, and not something they necessarily have, which is how the term gender has been understood at the beginning. In other words, the term has been introduced to depict that gender is a matter of choice, while it is often mistakenly used as a polite expression for sex (Scott, 1999). According to Butler (2004), gender is a matter of culture and social interactions and mostly a matter of choice. When it comes to PR, some authors have argued that PR suffers 
from the way people do gender because everyone becomes affected by expectations and stereotypes, and because of that organisations also became gendered (Place, 2015).

On the other hand, it can be argued that genderlect is not something people choose, i.e. it is rather something that comes from the socialisation process, which is not the same for boys and girls as they are growing up. In other words, boys and girls socialise in different ways and because of that, they learn to communicate in different ways. If socialisation is largely conditioned by patriarchy then obviously differences in communication as well as behaviour will be even stronger. As also emphasized by Tannen (1986: 125) "male-female conversation is cross-cultural communication. Culture is simply a network of habits and patterns gleaned from past experience, and women and men have different past experiences". In addition, boys and girls have different experiences because they "grow up in different worlds, even if they grow up in the same house. And as adults they travel in different worlds, reinforcing patterns established in childhood" (Tannen, 1986: 125). Because of that, and the fact they look for status (boys) or intimacy (girls) in their social interactions and communication styles (Tannen, 1990), their language is also different. Blair (2000) researched genderlect in schools and found that boys curse more than girls and often use homophobia to re-enforce their status (e.g. by using terms such as faggot or gay) as well as female terms, or saying that men are doing something like a girl to re-enforce their masculinity). On the other hand, girls are more inclined to use qualifiers such as "kind of", "sort of” and similar (Parkhurst, 2012).

The communication differences also affect leadership styles between men and women, as well as gender relations in the work place. However, these differences are a subject of interest of the feminist movement only since the inception of the third wave of feminism (Merchant, 2012) even though certain feminists argued that women have always been subject to discrimination at work (Hartmann, 1976; for a review see Fitch, 2016). 
According to available information, women are still not occupying senior managerial positions even if they managed to enter all professions, and this is one of the foci's of the third wave of feminism where the activists are demanding higher inclusion of women to more senior positions (Merchant, 2012). The activism has been successful to a certain extent and there is a slow increase in number of women occupying senior positions. The third wave has not finished yet, as feminists still advocate more inclusion of women to politics and managerial positions, equality at work, as well as equal rights for minority women (Merchant, 2012). The feminists also protest against the so-called "glass ceiling", or a situation where women can progress in their careers until a certain point and then they cannot go any higher (Baxter \& Wright, 2000; Merchant, 2012; Tench \& Topić, 2016). However, the problem with successfully combating the glass ceiling problem is in women's denial of a glass ceiling where women, when asked, do not report the problem but blame themselves for not progressing in their careers (Wrigley, 2002).

Just like with research on women in PR and communication differences between men and women, when it comes to gender and leadership most studies assume differences between women and men when exercising leadership. However, there are also studies that refute the differences, or at least underline that there are another stronger contextual variables to explain the diversity than the variable of gender.

Most of the research about gender and leadership has focused on finding differences in the styles of leadership of women and men. Munduarte (2003) found these studies are based on a rational of two steps: a) men and woman lead differently and b) masculine characteristics are associated with effective leadership. In addition, diverse empirical studies have contested the hypothesis of stereotyped differences. For example, results of Cuadrado et al. (2003) show that there are higher correlations in women than in men, in self-perceived behaviour, between good leadership styles and male stereotyped styles of authority, control and objective-orientation. 
Differences on access to leadership positions can also be explained by gender stereotypes. The pioneer studies of Schein (1973) found that both women and men perceived leadership efficacy associated to the characteristic behaviours of men. The sentence "think manager-think male" means that a good leadership style is associated with male stereotyped styles (Schein, 2001) and may imply a factor of discrimination when women and men compete for a leading position.

Eagly \& Karau (2002) proposed the theory of role congruity which explained the prejudices to women through the non-congruence between leadership and female roles. What is most commonly associated with problems in female progress to managerial position is stereotypes associated with women, i.e. their caring nature that encompasses personal characteristics such as a friendly approach, emotional nature, affectionate attitude, sensitivity and similar, while men are associated with rationality, unemotional attitudes, aggressive approach, etc. (Schneider, 2005). These differences portray men as suitable for effective leadership, while women appear to lack these essential qualities such as an aggressive approach and rationality. Because of that, women are seen as inadequately equipped for taking higher managerial positions.

Therefore, in this research we have focused on preferred methods of communication and the characteristics of effective leadership as self-assessed by PR practitioners across Europe. This focus enables us to contribute to the debate on communication differences between men and women, characteristics of an effective leader in regards to necessary communication skills and these findings can then give an indication on whether there is a genderlect issue that requires further interrogation in other research studies. The research predominantly looks to research whether there are differences between men and women when it comes to preffered communication methods, and whether traditional stereotypes of women can be seen as truthful, i.e. are women truly committed towards building intimacy and relationship by preferring face to face communication? 


\section{Method}

The questionnaire was sent to PR and communications practitioners, and it consisted of 18 sections and 39 questions. In this article, we are presenting and discussing results from sections on communication and leadership styles, however, the questionnaire also examined problems such as networking, mentoring, business environment, etc.

The survey was conducted online, and before the official publication and call for participation, the questionnaire was pre-tested with 44 practitioners from 16 European countries. The final questionnaire was published in March 2014, and the survey was open for four weeks.

Firstly, personal invitations for participations were sent to 30,000 practitioners in Europe based on database provided by the European Association of Communication Directors (EACD). Secondly, personal invitations were sent to practitioners via national research and professional organizations. In total, 2,881 practitioners completed the survey. Answers from practitioners who could not be identified as part of the selected population were deleted from the dataset. The final number of responses that are subject of the analysis was then set to 2,777 responses.

Two thirds of respondents were communication leaders, i.e. $40 \%$ hold a top hierarchical position as head of communication or as CEO of a communication consultancy, $27.6 \%$ were unit leaders, $26.1 \%$ were team members or consultants, $57.7 \%$ have more than 10 years of experience in communication management, and $61.7 \%$ were female. Majority of respondents have an academic degree $(94.1 \%)$, and two thirds of respondents hold a graduate degree or a doctorate.

The practitioners were asked to give their personal views on which communication methods they prefer, what is the most important means of communication in the current industry landscape, what are the characteristics of an effective leadership and to state what they think 
are the characteristics of male and female practitioners. The results were then compared per gender, and are analysed against the theoretical discussion presented earlier in this paper.

The research questions addressed in this study were set as follows: What is the preferred method of communication among male and female communications practitioners? What communications practitioners perceive as the most important means of communication for the industry? What are the characteristics of effective leadership according to the views of communications practitioners? Can we speak of differences in preferred communication styles between men and women?

\section{Results}

When it comes to preferred methods of communication results show differences that go against popular difference approach in communication styles among men and women. If we take into consideration that the difference approach sees women and men as different and where men are seen as less compassionate and more task-oriented, while women are seen as more interested in building relationships with their employees through interpersonal communication (Eagly \& Johnson, 1990; Gray, 1992; Eagly, 1987; Eagly \& Karau, 2002; Martell \& DeSmet, 2001), it is quite interesting that the results show that women are more inclined to use emails and social media as methods of communication with their colleagues while men prefer faceto-face and phone calls. In other words, and as presented in figure 1, 40.4\% of women prefer email as their communication channel, while $34.5 \%$ of men prefer the same method. On the other hand, social media is again preferred by women $(28.0 \%$ versus $25.4 \%$ in favour of women). When it comes to face-to-face and phone communication, then it is male practitioners who prefer these channels, i.e. $27.7 \%$ of men and $20.8 \%$ of women. The situation is similar with phones, where $9.3 \%$ of women and $11.3 \%$ of men prefer this channel.

\section{Figure 1: Preferred Methods of Communication}




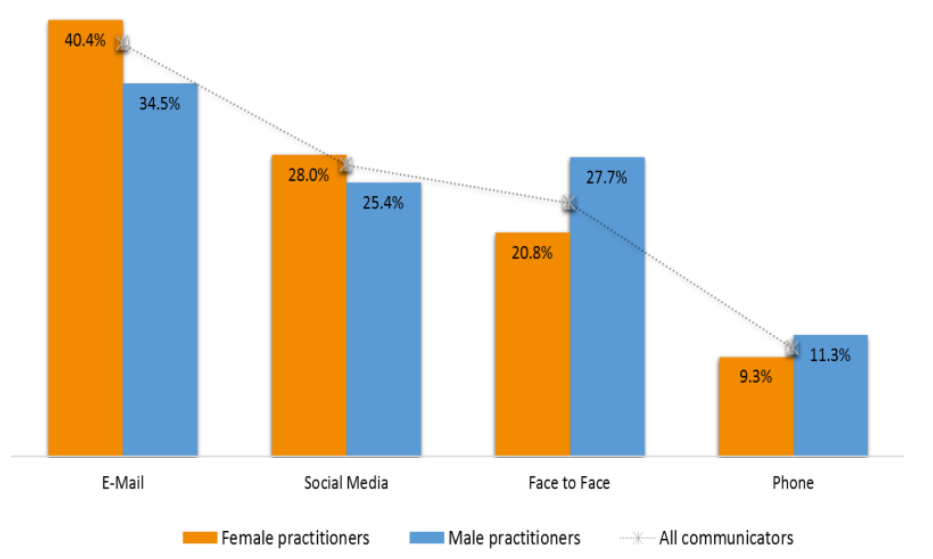

Men are, as discussed above seen as task oriented, while women are seen as relationship oriented, and while task orientation might have something to do with face-to-face and phone preferences, it is quite inexplicable how emails and social media fit into compassionate and caring leadership methods meant to build intimacy and personal relationships, which is how women are traditionally seen. Nevertheless, it is widely accepted that the social media changed the way we communicate and some scholars argued that social media communication does not deepen our conversations as much as face-to-face communication does (Keller, 2013) due to its mediated nature. In other words, mediated communication is seen as communication process carried out via technology and thus can also be seen as contrasted to face-to-face communication. For example, some authors argued that there are three main forms of communication interactions, i.e. face-to-face, mediated, and quasi-mediated with face-to-face communication also involving gestures and non-verbal communication and thus requiring physical presence (Crowley and Mitchell, 1994; Waldeck et al, 2012).

Thus, these results might actually signal that women managers are more inclined towards rationality and professionalism in their approach, while men seem to be more inclined to build personal relationships with their employees even if they are more task-oriented. 
Nevertheless, women actually follow trends better with their preferred method of communication, because practitioners generally recognized that the most important means of communication is online communication. As presented in figure 2, 85.9\% of practitioners recognised online communication as the most relevant communication method for the industry.

\section{Figure 2: The Most Important Means of Communication for the Industry}

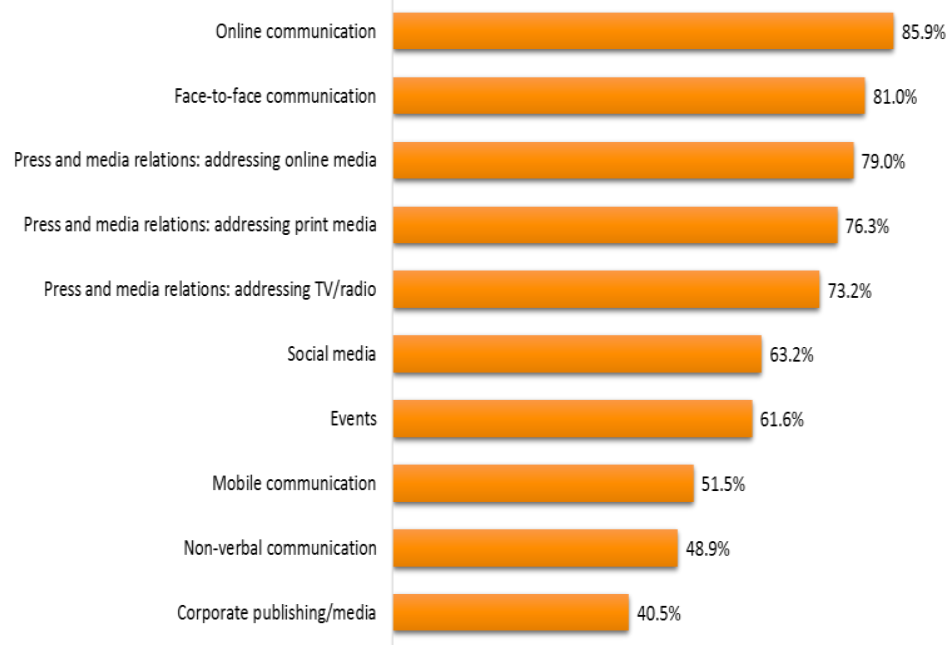

In other words, if we look at figures 1 and 2, it appears that it is women who follow the trends and lean towards appropriate way of communication to achieve business goals even though this communication method is not a personal form of communication that should help in building relationships. This result may also be the case due to stereotypes of women and the fact they progress harder as already discussed, however, it does indicates that women do not lean towards compassion or emotional leadership and work ethics, but a rational one based on trends in the current industry.

When we look at views of communication practitioners on what constitutes effective leadership, we see that the perceived most important characteristic for effective leadership in public relations is communication in an open and transparent way that can be seen to be closer to the consensus on leadership performance. As presented in figure 3, communicating in an open and transparent way is appreciated by $94.7 \%$ of practitioners, providing a clear overall, 
long-term vision by $90.9 \%$, and handling controversial issues or crises calmly and confidently by $90.1 \%$.

\section{Figure 3: Characteristics of an Effective Leadership}

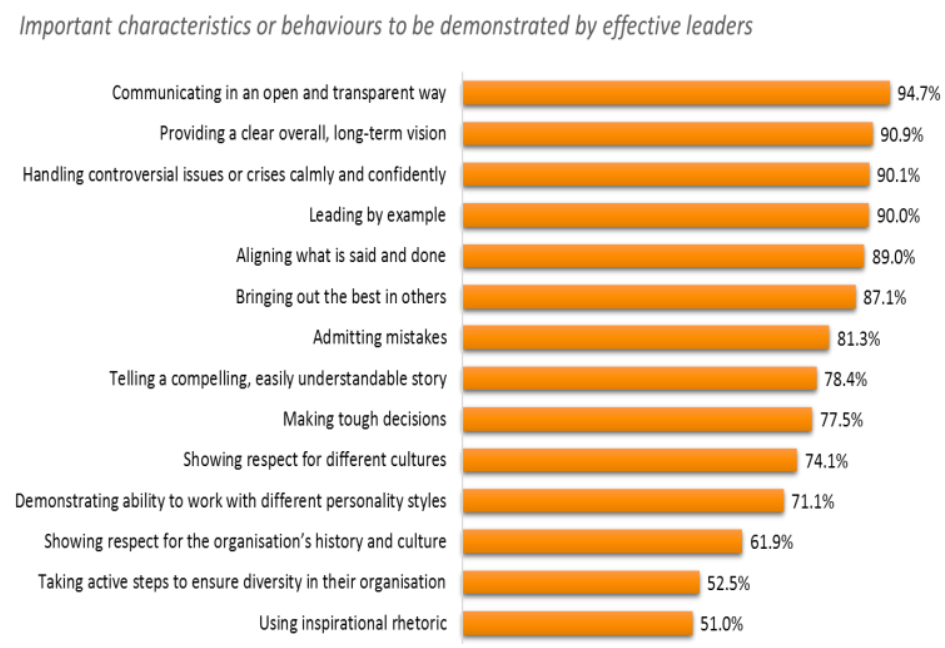

This result is congruent with the widely accepted symmetrical and dialogic prescriptive models of public relations. It is also relevant to note that two of the top three characteristics seen as more effective for good leadership are more reminiscent of the male stereotyped styles based on objective-orientation. In any case, women have more expectations with regard to all the analysed characteristics of effective leadership, but results do not show a preference of female practitioners for stereotyped feminine styles or with men for stereotyped male styles of leadership, which is in line with more recent studies in gender and leadership styles (Molero, 2009). In other words, effective leadership entails - among others - communicating in an open and transparent way.

When it comes to personal characteristics ascribed to women, practitioners report traditional views on differences between men and women, where men are seen as more aggressive, able to promote themselves, self-confident, politically savvy, more motivated for managerial positions, more analytical, and with stronger managerial and operational skills (figure 4). On the other hand, women are seen as more emotional and sensitive to people (also figure 4). 


\section{Figure 4: Personal Characteristics of Male and Female Practitioners}

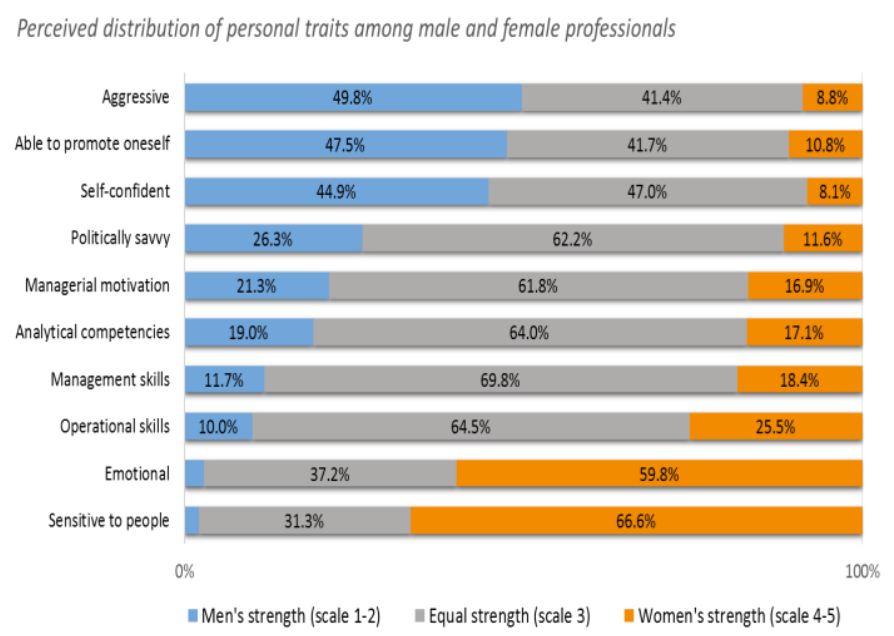

These views largely fit into stereotypes against women as compassionate and emotional while men are more predisposed for managerial and leadership position. On the other hand, there is a downfall in characteristics ascribed to men when it comes to managerial motivation, analytical competences, and managerial and operational skills. This means that women are slowly finding their way through acknowledgement of their efforts and an increase in selfesteem; however, they are still seen as emotional and compassionate as opposed to men, which fits into traditional stereotypes against women (Van Zoonen, 2004; Eichenbaum \& Orbach, 1999; Templin, 1999).

\section{Conclusion}

As we have discussed in the theoretical part of the article, women are still seen through prejudicial views, and still face certain problems on the road to full equality with men such as the wage gap, the glass ceiling, as well as stereotyped decision-making processes when it comes to leave of absence for family reasons to both men and women. On the other hand, when it comes to communication differences, men are seen as committed to independence, competitiveness and enforcing status while women are seen as committed to creating connections, relationships and intimacy. These differences are seen to affect leadership as well, 
where the so-called traditional or stereotyped male characteristics are perceived as desirable for effective leadership and not the alleged female characteristics.

Contrary to views of women as more compassionate and committed to creating relationship and intimacy, our results have indicated that prejudices are just prejudices, and female and male public relations practitioners do not seem to show great differences in their perception of effective leadership. Moreover, it is actually women practitioners who act in line with the online tendencies in the industry. In other words, all practitioners state that online communication is the most important form of communication in the present, and it is women that understand this through their preference for emails and social media communication channels. This goes not only against existing prejudicial views but also against even more sympathetic perceptions of gender communication differences that argues women and men are different in their communication styles due to different socialisation processes.

Our research has shown that the initial socialisation process, even if it would be conducted in a traditional male-female role assigning way, has no impact on the behaviour of women in the business world. On the other hand, the results of this research have suggested that it is men who prefer face-to-face talks and phone calls as the preferred methods of communication even though they recognize the importance of online communication. This research has demonstrated that the communication and leadership style of women challenges the usual views of the difference approach based on socialisation and genderlect. In other words, women should not be seen through stereotypes nor should their performance and leadership potential be judged according to alleged communication style. If anything, women should be seen as individuals and adaptive to changed circumstances of the industry and thus highly competent to take leadership roles. 
Consequently, future research should take into account diverse contextual and situational factors and look at the socialisation process of younger females to establish whether the socialisation process has been changing, as well as to establish if there are differences within various industries. In addition, further research is necessary to validate findings from this research as this was just one study conducted on one 'female' industry based within democratic normative principles in a particularly highly industrialised and democratised region of the world.

\section{References}

Alaez-Aller, Ricardo, Longas-Garcia, Juan Carlos and Miren Ullibari-Arce (2011). 'Visualising Gender Wage Differences in the European Union'. Gender, Work and Organization 18(1): 49-87.

Aldoory, Linda (2005). 'A (re) conceived feminist paradigm for public relations: A case for substantial improvement'. Journal of Communication 55(4): 668-684.

Aldoory, Linda and Elizabeth Toth (2002). 'Gender Discrepancies in a Gendered Profession: A Developing Theory for Public Relations'. Journal of Public Relations Research 14(2): 103126.

Barberá, Ester; López, Amparo and Carlos Agulló (2011). 'Laberinto de cristal en el liderazgo de las mujeres'. Psicothema, 23(2): 173-179. 
Bass, Bernard M. (1999). 'Two decades of research and development in transformational leadership'. European journal of work and organizational psychology, 8(1): 9-32.

Bass, Bernard M. (1998). Transformational leadership: Industry, military, and educational impact. Mahwah N.J: Erlbaum.

Bass, Bernad M.; Bruce J. Avolio and Leanne Atwater (1996). 'The transformational and transactional leadership of men and women'. Applied Psychology, 45(1): 5-34.

Bass, Bernard M. and Bruce J. Avolio (1994).' Shatter the glass ceiling: Women may make better managers'. Human resource management, 33(4): 549-560.

Bass, Bernard M. and Bruce J. Avolio (1990). Transformational leadership development: Manual for the multifactor leadership questionnaire. Palo Alto: Consulting Psychologists Press.

Bass, Bernard M. (1985). Leadership and performance beyond expectations. Free Press; Collier Macmillan.

Baxter, Janeed and Erik O. Wright (2002). 'THE GLASS CEILING HYPOTHESIS: A Comparative Study of the United States, Sweden, and Australia'. Gender \& Society 14(2): 275294.

Blair, Heather A. (2000). 'Genderlects: Girl talk and boy talk in middle years classroom'. Language Arts 77: 315-323. 
Butler, Judith (2004). Undoing gender. New York: Routledge.

Butler, Judith (1990). Gender trouble. New York and London: Routledge.

Cameron, Deborah, McAlinden, Fiona and Kathy O’Leary (1989). 'Lakoff in context: the social and linguistic functions of tag questions'. In D. Cameron and J. Coates (eds.) Women in Their Speech Communities. New York: Longman.

CIPR State of the Profession (2015). Results of survey on the wage gap between men and women in Public Relations. Retrieved 23 July 2015 from: http://www.cipr.co.uk/stateofpr

Coates, Jennifer (1989). 'Gossip revisited: language in all-female groups’. In D. Cameron and J. Coates (eds.) Women in Their Speech Communities. New York: Longman.

Crowley, David J. and David Mitchell (1994). Communication Theory Today. Stanford: Stanford University Press.

Cuadrado, Isabel; Molero, Fernando and Maria Navas (2003). 'El liderazgo de hombres y mujeres: diferencias en estilos de liderazgo, relaciones entre estilos y predictors de variables de resultado organizacional'. Acción Psicológica, 2: 115-129.

Dickenson, Donna (1993). Margaret Fuller: Writing a Woman's Life. New York: St.

Martin's. 
Dozier, Raine (2010). 'Accumulating Disadvantage: The Growth in the Black-White Wage Gap Among Women'. Journal of African American Studies 14: 279-30

Dozier, David; Sha, Bey-Ling and Masako Okura (2007). 'How Much Does My Baby Cost? An Analysis of Gender Differences in Income, Career Interruption, and Child Bearing'. Public Relations Journal 1(1): 1-6.

Eagly, Alice H. (1987). Sex differences in social behavior: A social-role interpretation. Hillsdale, NJ: Erlbaum.

Eagly, Alice H. and Mary C. Johannesen-Schmidt (2001). 'The leadership styles of women and men'. Journal of social issues, 57(4): 781-797.

Eagly, Alice H. and Blair T. Johnson (1990). 'Gender and Leadership Style: A MetaAnalysis'. Psychological Bulletin 108: 233-256.

Eagly, Alice H. and Steven J. Karau (2002). 'Role congruity theory of prejudice toward female leaders'. Psychological review, 109(3): 573-598.

Eichenbaum, Luise and Susie Orbach (1999). What do Women Want? Exploding the Myth of Dependency. New York: Berkley Books. 
Engen, Marloes.; Leeden, Rien Van der and Tineke M. Willemsen (2001). 'Gender, context and leadership styles: A field study'. Journal of occupational and organizational psychology, 74(5): 581-598.

Ersoy, Selma (2008). Men compete, women collaborate: A study on collaborative vs. competitive communication styles in mixed-sex conversations. The Teacher Education, The C-level of English Linguistics. Retrieved 22 July 2015 from: http://www.divaportal.org/smash/get/diva2:231309/fulltext01

Eveline, Joan and Patricia Todd (2009). 'Gender Mainstreaming: The Answer to the Gender Pay Gap?' Gender, Work and Organization 16(5): 536-558.

Fitch, Kate (2016a). 'Feminism and Public Relations'. In J. L'Etang; S. McKie; N. Snow and J. Xifra (eds) The Routledge Handbook of Critical Public Relations. London: Routledge.

Fitch, Kate; James, Melanie and Judy Motion (2016). 'Talking back: Reflecting on feminism, public relations and research'. Public Relations Review 42: 279-287.

Fitch, Kate and Amanda Third (2010). 'Working girls: Revisiting the gendering of public relations'. PRism 7(4). Retrieved 23 July 2015 from: http://www.prismjournal.org/fileadmin/Praxis/Files/Gender/Fitch_Third.pdf 
Fröhlich, Romi and Sonja B. Peters (2007). 'PR bunnies caught in the agency ghetto? Gender stereotypes, organizational factors, and women's careers in PR agencies'. Journal of Public Relations Research 19(3): 229-254.

Goldberg, Michelle (1994). 'Sex Stereotypes as a Function of Genderlect'. Totem: The University of Western Ontario Journal of Anthropology 1(1), 75-79. Article 13. Retrieved 27 July 2015 from: http://ir.lib.uwo.ca/totem/vol1/iss1/13

Goldman, Jane (2001). The Feminist Aesthetics of Virginia Woolf. Cambridge: Cambridge University Press.

Gray, John (1992). Men are from Mars, Women are from Venus: a Practical Guide for Improving Communication and Getting What You Want in a Relationship. New York: HarperCollins.

Grunig, Larissa A.; Toth, Elizabeth L. and Linda C. Hon (2001). Women in Public Relations: How gender influences practice. New York: The Guilford Press.

Hartmann, Heidi (1976). 'Capitalism, Patriarchy, and Job Segregation by Sex'. Signs 1(3): 137169.

Hochschild, Arlie R. (2008). 'Emotion work, feeling rules, and social structure'. In M. Greco and P. Stenner (eds.) Emotions: A social science reader. Abingdon and New York: Routledge. 
Hochschild, Arlie R. (2003). The managed heart: Commercialization of human feeling ( $2^{\text {nd }}$ edition). Berkeley, CA: University of California Press.

Hochschild, Arlie R. (1983). The managed heart: Commercialization of human feeling. Berkeley, CA: University of California Press.

Houchin-Winfield, Betty (1997). 'The Making of an Image: Hillary Rodham Clinton and American Journalists’. Political Communication 14: 241-253.

Katila, Saija and Susan Meriläinen (2002). 'Metamorphosis: From 'Nice Girls' to 'Nice Bitches': Resisting Patriarchal Articulations of Professional Identity’. Gender, Work and Organization 9(3): 336-354.

Keller, Maura (2013). Social Media and Interpersonal Communication. Social Work Today 13(3): 10 .

Labelle, Real, Francoeur, Claude and Faten Lakhal (2015). 'To Regulate Or Not To Regulate? Early Evidence on the Means Used Around the World to Promote Gender Diversity in the Boardroom'. Gender, Work and Organization 22(4): 339-363.

Lakoff, Robin (1975). Language and Woman's Place. New York: Harper and Row. 
Lamude, Kevin G. (1993). 'Supervisors' upward influence tactics in same-sex and cross-sex dyads'. Perceptual and Motor Skills 77: 1067- 1070.

Leaper, Campbell (1991). 'Influence and involvement in children's discourse: Age, gender, and partner effects'. Child Development 62: 797-811.

Lehmann, Christine (2001). 'Women psychiatrists still battle Freud's view of sexes'. Psychiatric News 36(14). Retrieved 22 May 2017 from:

http://psychnews.psychiatryonline.org/doi/10.1176/pn.36.14.0009

Maltz, Daniel N. and Ruth A. Borker (1982). 'A cultural approach to male-female miscommunication'. In J. J. Gumperz (ed.) Studies in Interactional Sociolinguistics, No. 2. Cambridge: Cambridge University Press.

Martell, Richard F. and Aaron L. DeSmet (2001). 'Gender stereotyping in the managerial ranks: A Bayesian approach to measuring beliefs about the leadership abilities of male and female managers'. Journal of Applied Psychology 86: 1223-1231.

Mason, Sharon. (1994). 'Gender differences in job satisfaction'. The Journal of Social Psychology 135: 143-151.

McCann, Carole, \& Seung-kyung Kim (2003). Feminist Theory Reader: Local and Global Perspectives. New York: Routledge. 
Merchant, Karima (2012). 'How Men and Women Differ: Gender Differences in Communication Styles, Influence Tactics, and Leadership Styles'. CMS Senior Theses. Paper 513. Retrieved 22 July 2015 from:

http://scholarship.claremont.edu/cgi/viewcontent.cgi?article $=1521 \&$ context $=\mathrm{cmc}$ theses

Molero, Fernando (2009). Mujer y liderazgo en el siglo XXI. Una aproximación psicosocial a los factores que dificultan el acceso de la mujer a los puestos de alta responsabilidad, Retrieved 12 September 2015 from:

http://www.inmujer.gob.es/areasTematicas/estudios/estudioslinea2009/docs/mujerLiderazgo. pdf

Munduate, Lourdes (2003). 'Género y liderazgo. Diferencias entre hombres y mujeres en el acceso a los puestos directivos'. Revista de psicología Social, 18(3): 309-314.

Norton, Mary Beth (2005). A People and a Nation: a history of the United States. New York: Houghton Mifflin Company.

O’Neil, Julie (2003). ‘An Analysis of the Relationships Among Structure, Influence, and Gender: Helping to Build a Feminist Theory of Public Relations'. Journal of Public Relations Research 15(2): 151-179.

Parkhurst, Howard B. (2012). 'The Case of the Missing Male Reader: Implications of Genderlect and the Reality Principle'. American Secondary Education 41(1): 14-30. 
Place, Katie R. (2015). 'Binaries, continuums, and intersections: Women public relations professionals' understandings of gender'. Public Relations Inquiry, 4(1): 61-78.

Rush, Ramona R., Oukrop Carole E. and Pam Creedon (2004). Seeking equity for women in journalism and mass communication education: a 30-year update. New Jersey: Laurence Erlbaum Stanford.

Scharrer, Erica (2002). 'An 'improbable leap': a content analysis of newspaper coverage of Hillary Rodham Clinton's transition from first lady to Senate candidate'. Journalism Studies 3: $393-407$.

Schein, Virginia E. (2001). 'A global look at psychological barriers to women's progress in management'. Journal of Social issues, 57(4): 675-688.

Schneider, David J. (2005). The Psychology of Stereotyping. New York: Guilford Press.

Scott, Joan W. (1999). 'Some reflections on gender and politics'. In M. M. Ferree; J. Lorber and B. B. Hess (eds.) Revisioning gender. Thousand Oaks, London, New Delhi: Sage.

Stainton-Rowgers, Wendy (2011). Social Psychology, $2^{\text {nd }}$ edition. New York: Open University Press and McGraw-Hill Education.

Suciu, Giulia (2013). 'Why Don't You Understand? Male-Female Communication'. The Round Table: Partium Journal of English Studies. Retrieved 22 July 2015 from: 
http://www.theroundtable.ro/Current/Language/Giulia_Suciu_Why_Don't_You_Understand_ Male.Female_Communication.pdf

Suciu, Giulia (2008). 'Talk-shows: A Reflection of Gender Inequalities?' The Round Table: Partium Journal of English Studies. Retrieved 22 July 2015 from:

http://www.theroundtable.ro/index.php?option=com_content $\& v i e w=\operatorname{article} \& \mathrm{id}=10 \&$ Itemid= $\underline{6}$

Teasdale, Nina (2013). 'Fragmented Sisters? The Implications of Flexible Working Policies for Professional Women's Workplace Relationships'. Gender, Work and Organization 20(4): $397-412$.

Tench, Ralph, \& Topić, Martina (2016). 'How Far Have We Got? A Longitudinal Analysis of Views of Public Relations Practitioners on the Position of Women in the PR Industry'. Paper presented at $7^{\text {th }} I H P R C$, Bournemouth University, Bournemouth, UK (6-7 July 2016).

Tannen, Deborah (1986). That's Not What I Meant! New York: Penguin Random House.

Tannen, Deborah (1990). You Just Don't Understand. New York: Penguin Random House.

Tannen, Deborah (1995). 'The Power of Talk: Who Gets Heard and Why'. Harvard Business Review, September-October: 139-149.

Templin, Charlotte (1999). 'Hillary Rodham Clinton as Threat to Gender Norms: Cartoon Images of the First lady'. Journal of Communication Inquiry 23: 20-36. 
Tindall, Natalie T.J. (2013). 'Invisible in a visible profession: The social construction of workplace identity and roles among lesbian and bisexual public relations professionals'. In N. T. J. Tindall and R. D. Waters (eds) Coming Out of the Closet: Exploring LGBT Issues in Strategic Communication with Theory and Research. New York: Peter Lang, 24-40.

Thornley, Carole and Christer Thörnqvist (2009). 'Editorial: State Employment and the Gender Pay Gap'. Work, Gender and Organization 16(5): 529-535.

Torenly, Nurcan (2006). 'The 'Other' Faces of Digital Exclusion: ICT Gender Divides in the Broader Community’. European Journal of Communication 21(4): 435-455.

Van Zoonen, Lisbeth (2004). Entertaining the citizen: when politics and popular culture converge. New York, Boulder, CO: Rowman and Littlefield.

Verboord, Mark (2012). 'Female bestsellers: A cross-national study of gender inequality and the popular-highbrow culture divide in fiction book production, 1960-2009'. European Journal of Communication 27(4): 395-409.

Zerfass, Ansgar; Vercic, Dejan; Verhoeven, Piet; Moreno, Angeles and Ralph Tench (2015). European Communication Monitor 2015. Creating communication value through listening, messaging and measurement. Results of a Survey in 41 Countries. Brussels:

EACD/EUPRERA, Helios Media. 
Zerfass, Ansgar; Van Ruler, Betteke; Rogojinaru, Adala; Vercic, Dejan and Sven Hamrefors (2007). European Communication Monitor 2007. Trends in Communication Management and Public Relations - Results and Implications. Leipzig: University of Leipzig/Euprera.

Waldeck, Jennifer H.; Kearney, Patricia and Timothy G. Plax (2012). Business and Professional Communication in a Digital Age. Andover: Cengage Learning, p. 1478.

White, Andrew (2003). Women's usage of specific linguistic functions in the context of casual conversation: Analysis and discussion. A module five assignment, University of Birmingham. Retrieved 22 July 2015 from:

http://www.birmingham.ac.uk/Documents/collegeartslaw/cels/essays/sociolinguistics/White5.pdf

Wood, Julia T. (1996). Gendered lives: Communication, gender, and culture ( $2^{\text {nd }}$ edition). Belmont, CA: Wadsworth.

Wrigley, Brenda J. (2002). 'Glass Ceiling? What Glass Ceiling? A Qualitative Study of How Women View the Glass Ceiling in Public Relations and Communications Management'. Journal of Public Relations Research 14(1): 27-55.

Wyatt, Ruth (2013). The PR Census 2013. PR Week. [online] Retrieved 2 April 2015 from: http://www.prweek.com/article/1225129/pr-census-2013 
Yeomans, Liz (2014). 'The gender gap in PR: What research tells us'. CIPR blog post, 10 March. Retrieved 21 July 2016 from: http://influence.cipr.co.uk/2014/03/10/the-gender-gapin-pr-what-research-tells-us/

Yeomans, Liz (2013). 'Gendered performance and identity work in PR consulting relationships: A UK Perspective'. In - C. Daymon and C. Demetrious (eds.) Gender and Public Relations: Critical Perspectives on voice, image and identity. London: Routledge.

Yeomans, Liz (2010). 'Soft sell? Gendered experience of emotional labour in UK public relations firms'. PRism 7(4). Retrieved 23 July 2015 from: http://www.prismjournal.org/fileadmin/Praxis/Files/Gender/Yeomans.pdf

Yule, George (2006). The Study of Language. Cambridge: Cambridge University Press. 